\title{
Camel hides: Production, marketing and utilization in pastoral regions of northern Kenya
}

\author{
Anastasia W Kagunyu ${ }^{1 *}$, Francis Matiri ${ }^{2}$ and Ellias Ngari ${ }^{3}$
}

\begin{abstract}
Camel hides are important sources of foreign exchange earnings for Kenya and other African countries. However, it has been observed that the full potential of camel hides has not been realized nor exploited in Kenya. This has been attributed to poor quality of hides which leads to low demand in both domestic and export markets. This led to the need for Kenya Agricultural Research Institute Marsabit Centre to conduct this study, which aimed at assessing the production, marketing and utilization of camel hides from northern Kenya. The study took place in major areas that produce and market camel hides in Kenya, namely Moyale, Marsabit, Isiolo, Garisa, Wajir (pastoral regions in arid and semi-arid areas ASALS) and Nairobi city. Research methods included semi-structured questionnaires, key informants, direct observation and documentary information. The results showed that camel hides were mainly sold in the big towns of northern Kenya and Nairobi. The study also indicated that camel hides were of poor quality due to poor flaying and curing methods. The study also revealed that most camel hides are used for domestic purposes. Pastoral communities need to be encouraged to sell their camel hides. There is a need to train camel keepers on appropriate methods of flaying and curing hides. There is a need for policy makers to consider improving the roads in the ASALS and to lower taxes charged on hides.
\end{abstract}

Keywords: Camel; KARI; Hides; ASALS; Northern Kenya

\section{Introduction}

Hides and skins are by-products of animals, and they are important and valuable resources (Leach and Trevor 2009) In Kenya, the hides, skins and leather industries contribute about $4 \%$ to the national agricultural gross domestic product (GDP) (Mbogo 2007). In the recent past, the country produced an average of 2.4 million cattle hides, 6 million skins and 20,000 camel hides (Mwinyijah and Magero 2009). It has been observed that the full potential of camel hides as a product has not been realized in Kenya and other African countries due to their poor quality, which is attributed to poor curing and flaying methods (AU-IBAR 2006).

This paper focuses on camel hides. According to Gitao (2006), camel hides are an important resource that could contribute a significant income to pastoralists if there is a reliable market and if they are properly cured. Hoyle (1994) observed that pastoral communities lacked proper methods of curing hides, leading to many being wasted or used in

\footnotetext{
* Correspondence: kagunyu2010@gmail.com

'KARI-Marsabit, P.O. Box 147-60500, Marsabit, Kenya

Full list of author information is available at the end of the article
}

beds as mats. Wayua et al. (2006) indicated that the potential for hides, skins and leather business in the pastoral areas of northern Kenya is estimated to be high, but it has not been realized as the prices offered by businessmen are very low. For camel keepers to get maximum profit from their camel hides, proper curing methods, flaying and proper animal husbandry practices are paramount. In order to address the problems related to the quality of camel hides, Kenya Agricultural Research Institute undertook a study whose objectives were as follows:

1. To establish the production status of camel hides in Kenya

2. To identify the utilization of camel hides in Kenya

3. To identify the marketing outlets of camel hides in Kenya

4. To identify the constraints in the value chain.

\section{Study areas}

The study was conducted in five tanneries in Nairobi and in five camel-producing pastoral districts of Kenya, namely Moyale, Marsabit, Isiolo, Garissa and Wajir. These regions 
were chosen as they are the major producers of hides and skins in Kenya, while Nairobi is the major market outlet of the products.

\section{Methods}

\section{Sampling size and data collection}

This study included both qualitative and quantitative data. Qualitative data was derived from direct observations and key informants. A total of 514 respondents were interviewed which included 454 producers and 66 traders of hides. The unit of study was household heads. Quantitative data was derived from a questionnaire. The questionnaire was prepared and pre-tested before embarking on field work, and the questions were based on the research objectives. The collected data was coded, keyed in and analysed using Statistical Package for Social Sciences (SPSS). During the analysis, descriptive statistics were used.

A systematic sampling technique was applied to select the pastoral producers for the interview. This was done by identifying purposively major camel-producing areas in the five counties of northern Kenya. Sketch maps of the selected regions were drawn, and landmarks in the selected settlements were identified. They included chiefs' camps, shopping centres, schools, churches, mosques and roads. Straight lines were drawn connecting two landmarks, for instance, a landmark in the north was joined to a landmark in the south, and landmarks in the west were joined to those in the east. The respondents were interviewed along those lines, e.g. starting from the first landmark, the first four households were skipped, and the fifth household was considered for the interview; this exercise continued until the designated sample size was achieved. Purposive sampling was applied to select traders, butchers and key informants.

Various data collection techniques included individual interviews with the help of semi-structured questionnaires, together with direct observation, whereby the researcher visited slaughter houses, stores and tanneries. Another method used was key informant interviews of people who had good information on the study topic. These included Kenya government officers responsible for hides and skins, traders, workers from different tanneries and local leather manufacturers.

\section{Findings}

\section{Status of camel hides as compared to cattle hides and} skins

The study revealed that most of the camel-producing communities have too much attachment to camels, and they are rarely slaughtered. They are very important for subsistence and social and religious functions. This study indicated that in areas where camels are reared, camel keepers prefer to slaughter small ruminants rather than either camels or cattle. This was reflected by the amount received from the sale of hides and skins stated by the sampled respondents from Isiolo, Wajir, Garissa, Marsabit and Moyale. According to the findings, the principal amount received by the sampled respondents was from the sale of their shoat skins, earning them Kenya shillings (KES) 21,954,000 (US\$ 274,425); their total income from selling cattle hides came second with KES 9,350,000 (US\$ 116,785 ), while sales from camel hides was the lowest with KES 1,322,000 (US\$ 16,525), as indicated in Figure 1.

\section{Preservation of camel hides}

The study found that camel hides were mainly cured by producers using traditional methods, i.e. ground drying and suspension drying (Figure 2). Only a few producers were using modern methods of curing, which is wet salting. The prices offered for sun-dried hides were very low at the secondary and tertiary markets. Low prices also discouraged some livestock owners from selling their camel hides. This study also revealed that only very few producers were aware of the wet salting method of hides and skins, which is the method preferred by the tanners. Out of the 454 producers interviewed, only $81(18 \%)$ had been trained on wet salting of hides and skins. The other $373(82 \%)$ had no knowledge about wet salting.

\section{Prices of camel hides at different market levels}

Camel hides were the least valued as compared to hides of cattle and skins from small ruminants. The prices of camel hides were the lowest, with no differences for all grades despite their weight, as compared to those of cattle, since the average weight of a wet-salted camel hide was 18 $\mathrm{kg}$, while that of a cow was $12 \mathrm{~kg}$. This study found that the prices of hides were determined by the different curing methods used. The prices at the producers' level of sundried hides (suspension-dried and ground-dried) were the lowest, ranging from KES 50 to 150 (US\$ 0.6 to 1.9). Those of raw hides ranged from KES 150 to 300 (US\$ 1.9

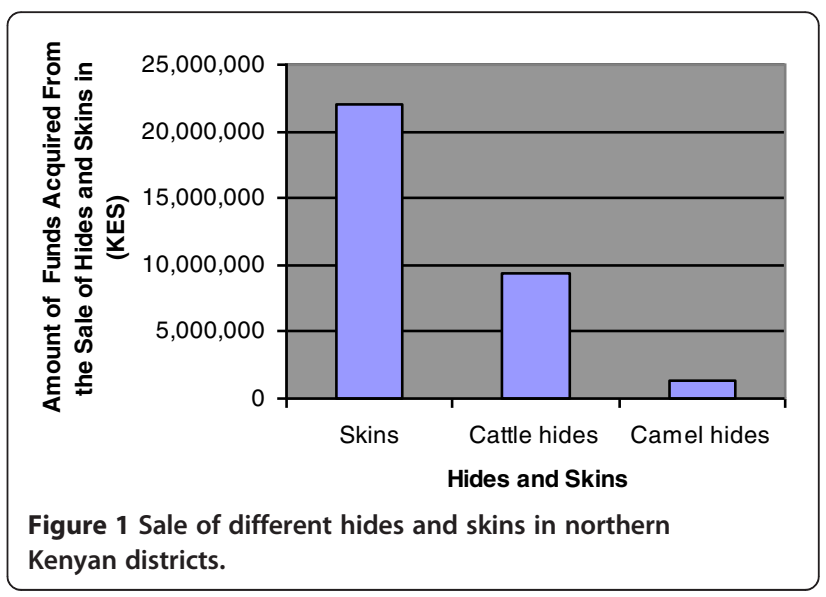




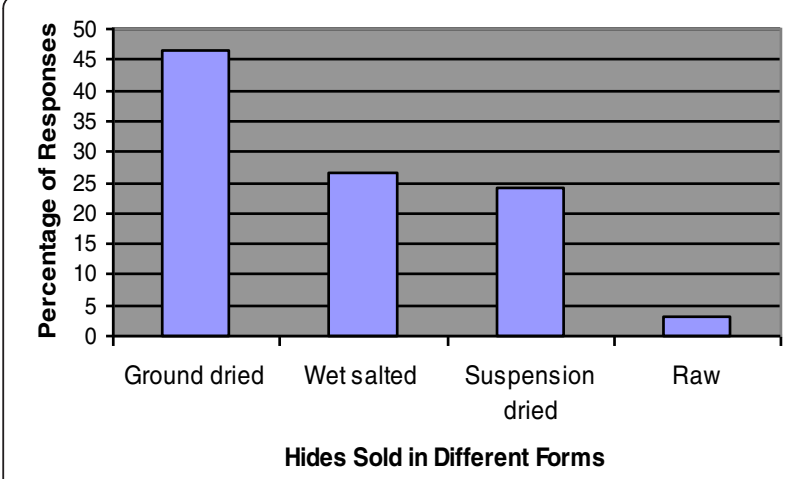

Figure 2 Different methods of preserving camel hides.

to 3.8), while the wet-salted had the highest price ranging from KES 300 to 600 (US\$ 3.8 to 7.6)

The prices of camel hides also varied at primarymarket level, depending on the curing methods. Sundried hide prices ranged from KES 150 to 300 (US\$ 1.9 to 3.8 ), while wet-salted hide prices ranged from KES 400 to 600 (US\$ 5 to 7.6). There were no raw hides as they were cured at the stores. At the tanneries, the prices of sun-dried camel hides ranged from KES 400 to 500 (US\$ 5 to 6.3), while the wet-salted hides were sold from KES 700 to 800 (US\$ 8.8 to 10). This study also revealed that camel hides were sold to five tanneries in Kenya, including Aziz Din, Mnasi, Zogo, Sagana and Bata leather tanneries (in Limuru town), and to the leather industries of Kenya in Thika town.

\section{Uses of camel hides}

Camel hides are important products that fulfil many functions. The hides are used to roof traditional houses of pastoral communities. The hides were also used for making ropes, guards, drums, seats, sandals, praying mats and water and milk containers. Among the Turkana community, hide and skins are eaten as food, and also other communities use them as famine food. This finding is in line with that of Field (2005) who indicated that hides are boiled and eaten for food by the Turkana community.

\section{Constraints facing production, marketing and utilization of camel hides}

The first problem identified was the limited markets of camel hides due to their poor quality attributed to poor curing methods, poor flaying and use of sharp knives which damage the skins. Poor transportation means was identified as one of the problems hindering camel hides from being taken to hides and skins markets.

\section{Recommendations}

This study finding indicated that the economic value of camel hides was low as compared to those of cattle hides and sheep/goat skins as most camel hides are used for domestic purposes. Pastoral communities need to be encouraged to sell their camel hides. Therefore, there is a need to train camel keepers on appropriate methods of flaying and curing of camel hides. Policy makers need to consider improving the roads in the arid and semi-arid areas of Kenya.

\section{Competing interests}

The authors declare that they have no competing interests.

\section{Authors' contributions}

AK, FM and EN collected the data and drafted most parts of the manuscript. AK and FM drafted the theoretical framework and revised the remaining parts. All authors read and approved the final manuscript.

\section{Acknowledgements}

The team wishes to thank the Kenya Agricultural Research Institute management for their financial support. Our appreciation goes to the producers and traders who provided us with the information, and the Kenya government Ministry of Livestock for offering technical advice.

\section{Author details}

${ }^{1}$ KARI-Marsabit, P.O. Box 147-60500, Marsabit, Kenya. ${ }^{2}$ KARI-Embu, P.O. Box 147-60500, Embu, Kenya. ${ }^{3}$ Ministry of Livestock and Development (Marsabit), P.O. Box 96-60500, Marsabit, Kenya.

Received: 16 August 2013 Accepted: 16 August 2013

Published: 20 September 2013

\section{References}

AU-IBAR. 2006. Kenya livestock sector study: An analysis of pastoralists' livestock products, market value chains and potential external markets for live animals and meat. Nairobi: African Union Interafrican Bureau for Animal Resources.

Field, C. 2005. Where there is no development agency: A manual for pastoralists and their promoters. Aylesford, UK: Natural Resources International.

Gitao, GC. 2006. Camel husbandry: A practical guide to camel husbandry. Nairobi: Immediate Communications.

Hoyle, D. 1994. Small scale rural leather tanning manual. London: Voluntary Services Overseas.

Leach, I, and R Trevor 2009. Value addition through hides and skins. Rome: FAO.

Mbogo, E. 2007. Hides and skins manual for the arid and semi arid lands of Kenya. Nairobi: ALLPRO.

Mwinyijah, M, and J Magero. 2009. The dilemma in marketing of camel (Camelus dromedarius) hides in Kenya: Paper Presented at 14th Annual Kenya Camel Forum (KCF) at Moyale, 25th-29th May.

Wayua, F, M Ngutu, B Nyamori, and A Kagunyu. 2006. Rural leather tanning as a potential livelihood option for settled pastoral households: The case of Laisamis Imani Women Group in Marsabit District, Kenya, Poster presented at the 10th KARI Biennial Scientific Conference, 12-17 November, 2006, KARI Headquarters, Nairobi.

doi:10.1186/2041-7136-3-25

Cite this article as: Kagunyu et al:: Camel hides: Production, marketing and utilization in pastoral regions of northern Kenya. Pastoralism: Research, Policy and Practice 2013 3:25. 